\title{
ОСОБЛИВОСТІ КЛІНІЧНОГО ПЕРЕБІГУ РЕВМАТОЇДНОГО АРТРИТУ, АСОЦІЙОВАНОГО З ВОRRELIA BURGDORFERI
}

\author{
○С. І. Сміян, В. В. Юськевич
}

Тернопільський національний медичний університет імені І. Я. Горбачевського МОЗ України

РЕЗЮМЕ. Із кожним роком усе актуальнішим стає вивчення інфекційних артритів в ревматологічній практиці, оскільки на сьогодні артрити, асоційовані з Borrelia burgdorferi (B. burgdorferi), є серйозною медико-біологічною та медико-соціальною проблемою з огляду на схильність до хронізації та розвитку уражень опорно-рухового апарату, що призводить до несприятливих наслідків - тривалої непрацездатності й інвалідизації людей різного віку та статі.

Мета - встановити особливості клінічного перебігу РА, асоційованого з В. burgdorferi.

Матеріал і методи. Під нашим спостереженням перебували 63 пацієнти віком від 19 до 73 років, що зверталися в ревматологічне відділення Тернопільської університетської лікарні. Серед них було 19 (30,15 \%) чоловіків і 44 (69,85 \%) жінки. Пацієнти були поділені на 2 групи: 34 (1 група) - хворі з PA, асоційованим з B. burgdorferi, 29 (2 група) - з ізольованим РА. Діагноз РА верифікований згідно з класифікаційними критеріями (ACR/EULAR 2010). Для аналізу інтенсивності болю було використано візуальну аналогову шкалу болю (ВАШ), для характеристики активності PA застосовували шкалу активності хвороби DAS 28. Специфічні IgM та IgG до комплексу B. burgdorferi визначали за допомогою реакції імунного блотингу.

Результати. При проведенні дослідження встановлено, що наявність B. burgdorferi у хворих на РА асоціювалась із швидшим розвитком захворювання та високим ступенем активності запального процесу. Серед обстежених з лабораторно підтвердженою B. burgdorferi була більша кількість пацієнтів позитивних за АТ до ЦЦП та РФ. Серед когорти обстежених на РА з B. burgdorferi продемонстровано високий процент хворих з наявністю кіст Бейкера та структурними змінами на рентгенограмі (Ro-грамі). Показники больового синдрому за BAШ були достовірно вищими у пацієнтів із РA, асоційованим з B. burgdorferi $(\mathrm{p}<0,05)$.

Висновки. Продемонстровано, що наявність B. burgdorferi серед когорти обстежуваних сприяє прогресуванню артриту, викликає тяжчу клінічну картину захворювання та є предиктором розвитку більш вираженого ступеня суглобової деструкції.

КЛючОВІ СЛОВА: ревматоїдний артрит; Borrelia burgdorferi; діагностика; кісти Бейкера; Лайм-артрит.

Вступ. РА - це системне автоімунне захворювання невідомої етіології, яке характеризується хронічним запаленням, що призводить до тканинної деформації суглобів. Перебіг РА різноманітний - від легкої і до можливої агресивної форми. Рання діагностика і лікування зменшують руйнування суглобів, дозволяють зберегти функцію і поліпшити виживання хворих [12].

Зв'язок між хронічним запаленняміпошкодженням суглобів широко висвітлений в сучасній літературі, зокрема, актуальність таких запальних маркерів як ШОЕ і СРБ. Пошкодження, незважаючи на зменшення активності запального процесу, може прогресувати, можуть розвиватися ерозії у пацієнтів без клінічних проявів значного запалення [13].

Лайм-артрит майже ніколи не викликає хронічного, симетричного поліартриту, що допомагає відрізнити його від ревматоїдного артриту [9-11]. Хвороба Лайма (ХЛ, кліщовий бореліоз, Лаймбореліоз, ЛБ) - природно-вогнищевий зооноз, який викликають борелії комплексу Borrelia sensu lato, що передаються людині трансмісивним шляхом при присмоктуванні іксодового кліща [1]. Лайм-Бореліоз - найпоширеніша трансмісивна інфекція, що трапляється в Європі, в тому числі й в Україні $[2,3]$.
На сьогодні відомо, що ураження суглобів $\epsilon$ пізнім проявом хвороби Лайма. Деякі пацієнти можуть повідомити про випадки укусу кліща або наявність мігруючої еритеми, артрит може бути проявом хвороби без попередніх ознак або симптомів хвороби Лайма $[4,5]$. Підвищена тяжкість артропатій на пізній стадії хвороби була охарактеризована у дослідженнях як синовіальна гіперплазія, інфільтрація мононуклеарних клітин у синовіальну оболонку, утворення запального ексудату над оболонками синовіальних клітин (утворення паннуса), руйнування хряща, а також ерозія кісток і суглобів [6]. 3 клінічного погляду, Лайм-артрит зазвичай асиметрично впливає на великі синовіальні суглоби [7]. У понад 90 \% випадків уражається колінний суглоб, гомілковостопний суглоб $\epsilon$ другим за частотою залучення у патологічний процес [8].

Артритичний синдром в ревматології окреслений багатьма запальними захворюваннями суглобів, але проблема їх поєднання з інфекційними чинниками залишається актуальною і потребує подальшого вивчення. Відомо, що хвороба Лайма, в тому числі й її пізній прояв - артрит може мати ізольований перебіг, а в інших випадках може запускати механізми виникнення інших 
Огляди літератури, оригінальні дослідження, погляд на форм артритів і обтяжувати їх перебіг. Запальні артрити, такі як ревматоїдний, реактивний або псоріатичний остеоартрит, можуть розвинутися протягом декількох місяців після хвороби Лайма, начебто спровоковані спірохетальною інфекцією $[14,15]$. Сучасні дослідження в цьому напрямку (Arvikar S. L. і співавт., 2017) свідчать, що при розвитку запального артриту на тлі хвороби Лайма клініцистам потрібно розрізняти пацієнтів, які мають активну інфекцію в суглобах, тих, хто має післяінфекційний Лайм-артрит, та пацієнтів з іншою формою запального артриту, що виникає за хворобою Лайма [16]. 3 іншого боку, в клінічній практиці відомі варіанти перебігу РА, які погано відповідають на стандартну терапію, а пошук причин такої ситуації не виключає її інфекційної природи, в тому числі й Borrelia burgdorferi. Тому ми вважали за доцільне обстежити пацієнтів з РА на предмет наявності інфікування Borrelia burgdorferi.

Мета - встановити особливості клінічного перебігу РА, асоційованого з B. burgdorferi.

Матеріал і методи. Під нашим спостереженням перебували 63 пацієнти віком від 19 до 76 років, що отримували лікування в ревматологічному відділенні Тернопільської університетської лікарні. Серед них було 19 (30,15 \%) чоловіків і 44 (69,85 \%) жінки. Пацієнти були поділені на 2 групи: 34 особи (1 група), хворі на РА, асоційований з B. burgdorferi (середній вік $(49,6 \pm 6,7)$ років), 29 осіб (2 група) - 3 ізольованим РА (середній вік $(57,82 \pm 4,6)$ років). Діагноз РА верифікований згідно з класифікацій- роблему, випадок з практики, короткі повідомлення ними критеріями ACR/EULAR (2010). Усім пацієнтам проводили стандартні обстеження відповідно до протоколу надання допомоги № 263 (11.04.2014р.). Специфічні IgM та IgG до комплексу B. burgdorferi визначали за допомогою реакції імунного блотингу. Статистичну обробку виконували з використанням t-критерію Стьюдента. Статистично значущими вважали відмінності при $\mathrm{p}<0,05$.

Результати й обговорення. Аналізуючи клінічну характеристику хворих (табл. 1) ми встановили, що давність захворювання була достовірно нижчою у пацієнтів 3 РА, асоційованим 3 B. Burgdorferi, порівняно з пацієнтами з ізольованими PA $(p<0,05)$. Визначення артралгічного статусу за ВАШ дозволило встановити достовірне збільшення больових відчуттів $(p<0,05)$ у пацієнтів з РА, асоційованим з В. burgdorferi. Кількість болючих та припухлих суглобів була достовірно більшою $(p<0,05)$ у пацієнтів з РА, асоційованим 3 B. burgdorferi. Практично втричі вищою була ранкова скутість суглобів, яка тривала понад 60 хвилин у обстежуваних з B. burgdorferi, тоді, як у пацієнтів з ізольованим РА ранкова скутість тривала в межах 30-60 хвилин. Аналогічна тенденція виявлена при аналізі індексу активності захворювання (DAS 28), у результаті якого встановлено, що РA в стадії середньої активності $(3,2-5,1)$ мали пацієнти з ізольованим РА, а РА з високою активністю мали хворі, в яких виявлено B. Burgdorferi $(>5,1)$.

Оцінка даних інструментальних методів обстеження виявила, що кількість пацієнтів зі струк-

Таблиця 1. Клінічна характеристика хворих

\begin{tabular}{|c|c|c|}
\hline \multirow[b]{2}{*}{ Показники } & \multicolumn{2}{|c|}{ Пацієнти n (\%) } \\
\hline & $\begin{array}{c}\text { хворі з РА, асоційованим } \\
\text { з B. burgdorferi } \\
\text { n=34 (53,97\%) }\end{array}$ & $\begin{array}{c}\text { хворі з ізольованим PA } \\
n=29(46,03 \%)\end{array}$ \\
\hline Вік, роки & $49,6 \pm 6,7$ & $57,82 \pm 4,6$ \\
\hline \multicolumn{3}{|l|}{ Стать: } \\
\hline чоловіки, n (\%) & $11(32,35)$ & $8(27,59)$ \\
\hline жінки, п (\%) & $23(67,65)$ & $21(72,41)$ \\
\hline Давність захворювання, роки & $5,21 \pm 3,08$ & $13,68 \pm 1,47^{*}$ \\
\hline ВАШ, мм & $68,85 \pm 3,22$ & $54,21 \pm 4,86^{*}$ \\
\hline \multicolumn{3}{|l|}{ Ранкова скутість: } \\
\hline$\leq 30, x B, n(\%)$ & $2(5,88)$ & $5(17,24)$ \\
\hline $30-60 \times B, n(\%)$ & $7(20,59)$ & $18(62,07)$ \\
\hline$\geq 60, x B, n(\%)$ & $25(73,53)$ & $6(20,69)$ \\
\hline Кількість болючих суглобів & $13,12 \pm 1,62$ & $5,08 \pm 2,96^{*}$ \\
\hline Кількість припухлих суглобів & $15,62 \pm 3,10$ & $6,18 \pm 2,34^{*}$ \\
\hline DAS 28 & $6,9 \pm 1,2$ & $3,5 \pm 0,89 *$ \\
\hline $\begin{array}{l}\text { Кількість пацієнтів з структурними } \\
\text { змінами на Rо-грамі, n (\%) }\end{array}$ & $26(76,47)$ & $12(41,38)$ \\
\hline $\begin{array}{l}\text { Кількість пацієнтів з кістами } \\
\text { Бейкера на УЗД, n (\%) }\end{array}$ & $14(41,18)$ & $2(6,90)$ \\
\hline
\end{tabular}

Примітка. *- різниця достовірна ( $<<0,05)$ у групах пацієнтів з РА, асоційованим з B. burgdorferi, та ізольованим PA. 
Огляди літератури, оригінальні дослідження, погляд на проблему, випадок з практики, короткі повідомлення турними змінами на Ro-грамі переважала кількість хворих з РА, асоційованим з В. burgdorferi, та кількість хворих, в яких виявлено кісти Бейкера. 3 цих даних випливає, що наявність B. burgdorferi негативно впливає на клінічний перебіг РА.

Аналіз лабораторних показників обстежених хворих (табл. 2) дозволив зробити висновок, що половина хворих з ізольованим РА виявилися негативними за АТ до ЦЦП, половина - позитивними, тоді, як в когорті обстежених з РА в асоціації 3 B. burgdorferi кількість пацієнтів з позитивними антитілами до ЦЦП була в 4,5 раза більшою, ніж кількість хворих з негативними антитілами. Оцінюючи показники ШОЕ ми встановили, що у понад половини хворих з РА, асоційованим з $B$. burgdorferi, показник виявився вищим 40 мм/год, що вказує на високу активність запального процесу, тоді як у групі обстежуваних з ізольованим РА показник був в межах 20-40 мм/год. Достовірно $(p<0,05)$ нижчі показники СРП виявлено у пацієнтів з ізольованим РА, порівняно з хворими, у яких PA перебігає в асоціації з В. burgdorferi.

Таблиця 2. Розподіл хворих за лабораторними показниками

\begin{tabular}{|c|c|c|}
\hline \multirow[b]{2}{*}{ Показники } & \multicolumn{2}{|c|}{ Пацієнти п (\%) } \\
\hline & $\begin{array}{c}\text { хворі з РА, асоційованим з } \\
\text { B. burgdorferi } \\
\mathrm{n}=34(53,97 \%)\end{array}$ & $\begin{array}{c}\text { хворі з ізольованим РА } \\
n=29(46,03 \%)\end{array}$ \\
\hline \multicolumn{3}{|l|}{ АТ до ЦЦП } \\
\hline Негативні, n (\%) & $6(17,65)$ & $14(48,28)$ \\
\hline Позитивні, n (\%) & $28(82,35)$ & $15(51,72)$ \\
\hline \multicolumn{3}{|l|}{$P \Phi$} \\
\hline Негативний, n (\%) & $9(26,47)$ & $19(65,52)$ \\
\hline Позитивний, n (\%) & $25(73,53)$ & $10(34,48)$ \\
\hline \multicolumn{3}{|l|}{ ШOE } \\
\hline Норма, n (\%) & $3(8,82)$ & $7(24,14)$ \\
\hline 20-40 мм/год, n (\%) & $9(26,47)$ & $18(62,07)$ \\
\hline Більше 40 мм/год, n (\%) & $22(64,71)$ & $4(13,79)$ \\
\hline СРП, г/л & $14,98 \pm 3,92$ & $6,1 \pm 1,27^{*}$ \\
\hline
\end{tabular}

Примітка: *- різниця достовірна ( $<<0,05)$ у групах пацієнтів з РА, асоційованим з B. burgdorferi, та ізольованим РА.

Висновки. Серед хворих, що перебували під нашим спостереженням, PA, асоційований з B. burgdorferi, діагностовано у 53,97 \% пацієнтів. Для цього артриту типовими виявилися інтенсивний больовий синдром з високим значенням ВАШ, значна активність запального синдрому, наявність гіпертрофічного синовіту, переважно колінного суглоба, з кістами Бейкера, що в сукупності сприяє прогресуванню артриту, викликає тяжчу клінічну картину захворювання. Раннє виявлення B. burgdorferi та їі елімінація може сприяти зменшенню агресивного перебігу РА.

\section{ЛІТЕРАТУРА}

1. Задорожна В. І. Лайм-бореліоз - особливо небезпечна інфекція. Загрози та ризики / В. І. Задорожна, А. О. Руденко, В. Ю. Клюс // Ветеринарна медицина. 2017. - № 103. - С. 30-32.

2. Андрейчин М. А. Небезпечна динаміка інфекційної захворюваності в Україні / М. А. Андрейчин // Інфекційні хвороби. - 2017. - № 2 (88). - С. 4-8.

3. Хвороба Лайма: етіологія та епідеміологія / М. А. Крижановська, Т. В. Бігуняк, О. С. Редько, К. О. Бігуняк // Фундаментальные и прикладные исследования: проблемы и результаты: збірник наукових доповідей. Гданськ, 2017. - С. 23-25.

4. Shapiro E. D. Lyme disease / E. D. Shapiro // New England Journal of Medicine. - 2014. - Vol. 370 (18). P. 1724-1731.

5. Autoimmune arthritides, rheumatoid arthritis, psoriatic arthritis, or peripheral spondyloarthropathy, following Lyme disease / S. L. Arvikar, J. T. Crowley, K. B. Sulka, A. C. Steеге // Arthritis Rheum. - 2017. - Vol. 69 (1). - P. 194-202.

6. Elevated levels of collagenase and prostaglandin $E_{2}$ from synovium associated with erosion of cartilage and bone in a patient with chronic Lyme arthritis / A. C. Steere, C. E. Brinckerhoff, D. J. Miller [et al.] // Arthritis and Rheumatism. - 1980. - Vol. 238 (5). - P. 591-599.

7. Lyme disease manifestations in the foot and ankle: a retrospective case series / J. R. Miller, K. W. Dunn, D. Braccia [et al.] // J. Foot Ankle Surg. - 2016. - Vol. 55. - P. 12411244. DOI: 10.1053/j.jfas.2015.06.006.

8. Lyme arthritis of the pediatric lower extremity in the setting of polyarticular disease / A. Aiyer, W. Hennrikus, 
Огляди літератури, оригінальні дослідження, погляд на J. Walrath [et al.] // J. Child. Orthop. -2014. - Vol. 8. - P. 359365. DOI: 10.1007/s11832-014-0602-3.

9. Зінчук О. М. Виявлення Лайм-бореліозу серед хворих на реактивний артрит. Клінічні та діагностичні аспекти / О. М. Зінчук // Інфекційні хвороби. - 2008. № 2. - C. 28-31.

10. Lyme arthritis of the pediatric lower extremity in the setting of polyarticular disease / A. Aiyer, W. Hennrikus, J. Walrath [et al.] // J. Child Orthop. - 2014.

11. Lyme arthritis: a comparison of presentation, synovial fluid analysis, and treatment course in children and adults / B. E. Daikh, F. E. Emerson, R. P. Smith [et al.] // Arthritis Care Res. - 2013. - Vol. 65 (12). - P. 1986-1990.

12. Distinguishing Lyme from septic knee monoarthritis in Lyme disease-endemic areas / J. K. Deanehan, A. A. Kimia, S. P. Tan Tanny [et al.] // Pediatrics. - 2013. Vol. 131 (3). - P. e695-701. DOI: 10.1542/peds.2012-2531.

13. Ткаченко М.В.Діагностична цінність визначення антитіл до anti-CCP, ревматоїдного фактору та маркерів запалення у хворих на ревматоїдний артрит / М.В.Ткаченко, М.Ю.Бабаніна, Г. С. Хайменова // Актуальні проблеми сучасної медицини: Вісник української медичної стоматологічної академії. - 2016. - № 2 (54).

14. Практическая ревматология, современные акценты / под ред. О. Б. Яременко // Справочник врача «Практическая ревматология, современные аспекты»К. : ООО Библиотека «Здоровье Украины», 2015. - 536 с.

15. Arvikar S. L. Diagnosis and treatment of Lyme arthritis / S. L. Arvikar, A. C. Steere // Infect. Dis. Clin. North Am. - 2016. - Vol. 29 (2). - P. 269-280.

16. Sjögren's syndrome and lymphadenopathy unraveling the diagnosis of Lyme diseas / S. I. Smiyan, I. Yo. Galaychuk, I. V. Zhulkevych [et al.] // Reumatologia. - 2019. Vol. 57 (1). - P. 59-62. DOI: https://doi.org/10.5114/ reum.2019.83242

17. Borrelious lymphadenopathy in oncology practice (clinical observations) / I. Y. Galaychuk, I. V. Zhulkevych, S. I. Smiyan [et al.] // Онкологія. - 2019. - T. 21, № 3. C. 251-253. DOI: 10.32471/oncology.2663-7928. t-21-32019-g.7896 URL : https://www.oncology.kiev.ua/article / 7896/boreliozna-limfadenopatiya-u-praktici-onkologa-kli nichni-sposterezhennya

\section{REFERENCES}

1. Zadorozhna, V.I., Rudenko, A.O., \& Klius, V.Yu. (2017). Laimborelioz - osoblyvo nebezpechna infektsiia. Zahrozy ta ryzyky [Lyme borreliosis is a particularly dangerous infection. Threats and risks]. Veterynarna medytsyna: Zbirnyk naukovykh prats - Veterinary Medicine: Collection of Scientific Works, 103, 30-32 [in Ukrainian].

2. Andreichyn, M.A. (2017). Nebezpechna dynamika infektsiinoi zakhvoriuvanosti v Ukraini [Dangerous dynamics of infectious morbidity in Ukraine]. Infektsiini khvoroby - Infectious Diseases, 2, 4-8 [in Ukrainian].

3. Kryzhanovska, M.A., Bihuniak, T.V., Redko, O.S. \& Bihuniak, K.O. (2017). Khvoroba Laima: etiolohiia ta epidemolohiia [Lyme disease: etiology and epidemiology]. Fundamentalnye i prykladnye issledovaniya: problemy $i$ rezultaty: zbirnyk naukovykh dopovidey - Fundamental and Applied Research: Problems and Results: A Collection of Scientific Reports. Hdansk. (pp. 23-25) [in Ukrainian].

4. Shapiro, E.D. (2014). Lyme disease. New England Journal of Medicine, 370 (18), 1724-1731.

5. Arvikar, S.L., Crowley, J.T., Sulka, K.B., \& Steere, A.C. (2017). Autoimmune arthritides, rheumatoid arthritis, psoriatic arthritis, or peripheral spondyloarthritis following Lyme disease. Arthritis \& Rheumatology, 69 (1), 194-202.

6. Steere, A.C., Brinckerhoff, C.E., Miller, D.J., Drinker, H., Jr Harris, E.D., \& Malawista, S.E. (1980). Elevated levels of collagenase and prostaglandin e2 from synovium associated with chronic lyme arthritis. Arthritis \& Rheumatism, 23 (5), 591-599.

7. Miller, J.R., Dunn, K.W., Braccia, D., Jr Ciliberti, L.J., Becker, D.K., Hollinger, J.K., \& Brand, S.M. (2016). Lyme disease manifestations in the foot and ankle: a retrospective case series. The Journal of Foot and Ankle Surgery, 55 (6), $1241-1244$
8. Aiyer, A., Hennrikus, W., Walrath, J., Groh, B., \& Ostrov, B. (2014). Lyme arthritis of the pediatric lower extremity in the setting of polyarticular disease. Journal of Children's Orthopaedics, 8 (4), 359-365.

9. Zinchuk, O.M. (2008). Vyiavlennia Laim-boreliozu sered khvorykh na reaktyvnyi artryt. Klinichni ta diahnostychni aspekty [Detection of Lyme borreliosis among patients with reactive arthritis. Clinical and diagnostic aspects]. Infektsiini khvoroby - Infectious Diseases, 2, 28-31 [in Ukrainian].

10. Aiyer, A., Hennrikus, W., Walrath, J., Groh, B., \& Ostrov, B. (2014). Lyme arthritis of the pediatric lower extremity in the setting of polyarticular disease. Journal of Children's Orthopaedics, 8 (4), 359-365.

11. Daikh, B.E., Emerson, F.E., Smith, R.P., Lucas, F.L., \& McCarthy, C.A. (2013). Lyme arthritis: a comparison of presentation, synovial fluid analysis, and treatment course in children and adults. Arthritis Care \& Research, 65 (12), 1986-1990.

12. Deanehan, J.K., Kimia, A.A., Tanny, S.P.T., Milewski, M.D., Talusan, P.G., Smith, B.G., \& Nigrovic, L.E. (2013). Distinguishing Lyme from septic knee monoarthritis in Lyme disease-endemic areas. Pediatrics, 131 (3), e695-e701.

13. Tkachenko, M.V., Babanina, M.Yu., \& Khaimenova, H.S. (2016). Diahnostychna tsinnist vyznachennia antytil do anti-CCP, revmatoidnoho faktoru ta markeriv zapalennia u khvorykh na revmatoidnyi artryt [Diagnostic value of determination of antibodies to anti-CCP, rheumatoid factor and markers of inflammation in patients with rheumatoid arthritis]. Aktualni problemy suchasnoi medytsyny: Visnyk Ukrainskoi medychnoi stomatolohichnoi akademii - Actual Problems of Modern Medicine: Bulletin of the Ukrainian Medical Dental Academy, 16, 2 (54), 187-191 [in Ukrainian]. 
Огляди літератури, оригінальні дослідження, погляд на проблему, випадок з практики, короткі повідомлення

14. Yaremenko, O.B. (Ed.). (2015). Prakticheskaya revmatologiya: sovremennyye aktsenty [Practical rheumatology, contemporary accents]. Kyiv: OOO Biblioteka "Zdorovye Ukrainy" [in Russian].

15. Arvikar, S.L., \& Steere, A.C. (2015). Diagnosis and treatment of Lyme arthritis. Infect. Dis. Clin. North Am., 29 (2), 269-280. doi: 10.1016/j.idc.2015.02.004.

16. Smiyan, S.I., Galaychuk, I.Yo., Zhulkevych, I.V., Nykolyuk, V.D., Komorovsky, R.R., Gusak, S.R., \& Bilozetsky, I. (2019). Sjögren's syndrome and lymphadenopathy unraveling the diagnosis of Lyme diseas. Reumatologia, 57 (1),
59-62. DOI: https://doi.org/10.5114/reum.2019.83242

17. Halaichuk, I.Y., Zhulkevych, I.V., Smiian, S.I., Nykoliuk, V.D., \& Komorovskyi, R.R. (2019). Boreliozna limfadenopatiia u praktytsi onkoloha (klinichni sposterezhennia) [Borrelious lymphadenopathy in oncology practice (clinical observations)]. Onkolohiia - Oncology, 21, 3 [in Ukrainian]. DOI: 10.32471/oncology.2663-7928.t-21-32019-g.7896 Retrieved from: https://www.oncology.kiev. ua/article/7896/boreliozna-limfadenopatiya-u-prakticionkologa-klinichni-sposterezhennya

\title{
ОСОБЕННОСТИ КЛИНИЧЕСКОГО ТЕЧЕНИЯ РЕВМАТОИДНОГО АРТРИТА, AССОЦИИРОВАННОГО С BORRELIA BURGDORFERI
}

\author{
ОС. И. Смиян, В. В. Юскевич
}

Тернопольский национальный медицинский университет имени И. Я. Горбачевского Мз Украины

PEЗЮМЕ. С каждым годом все более актуальным становится изучение инфекционных артритов в ревматологической практике, поскольку на сегодня артриты, ассоциированные с Borrelia burgdorferi (B. burgdorferi), являются серьезной медико-биологической и медико-социальной проблемой, учитывая склонность к хронизации и развитию поражений опорно-двигательного аппарата, что приводит к неблагоприятным последствиям - длительной нетрудоспособности и инвалидизации людей разного возраста и пола.

Цель - установить особенности клинического течения РА, ассоциированного с B. burgdorferi.

Материал и методы. Под нашим наблюдением находилось 63 пациента в возрасте от 19 до 73 лет, обращавшихся в ревматологическое отделение Тернопольской университетской больницы. Среди них было 19 (30,15 \%) мужчин и 44 (69,85 \%) женщины. Пациенты были поделены на 2 группы: 34 пациента (1 группа), больных РА, ассоциированным с B. burgdorferi, 29 пациентов (2 группа) - с изолированным РА. Диагноз РА верифицирован согласно классификационным критериям ACR/EULAR (2010). Для анализа интенсивности боли была использована визуальная аналоговая шкала (ВАШ), для характеристики активности РА использовали шкалу активности болезни DAS 28. Специфические IgM и IgG к комплексу B. burgdorferi определяли с помощью реакции иммунного блоттинга.

Результаты. При проведении исследования установлено, что наличие B. burgdorferiy больных РА ассоциировалось с быстрым развитием заболевания и высокой степенью активности воспалительного процесса. Среди обследованных с лабораторно подтвержденной B. burgdorferi было большее количество пациентов, положительных по АТ ЦЦП и РФ. Среди когорты обследованных РА с B. burgdorferi продемонстрирован высокий процент больных с наличием кист Бейкера и структурными изменениями на рентгенограмме (Ro-грамме). Показатели болевого синдрома по ВАШ были достоверно выше у пациентов с РА, ассоциированным с B. burgdorferi (p<0,05).

Выводы. Продемонстрировано, что наличие B. burgdorferi среди когорты обследуемых способствует прогрессированию артрита у пациентов, вызывает тяжелую клиническую картину заболевания и является предиктором развития более выраженной степени суставной деструкции.

КЛЮчЕВЫЕ СЛОВА: ревматоидный артрит; Borrelia burgdorferi; диагностика; кисты Бейкера; Лайм-артрит.

\section{FEATURES OF CLINICAL COURSE OF RHEUMATOID ARTHRITIS ASSOCIATED WITH BORRELIA BURGDORFERI}

\section{Horbachevsky Ternopil National Medical University}

SUMMARY. The study of infectious arthritis in rheumatology practice is becoming more and more relevant every year, since today the arthritis associated with Borrelia burgdorferi (B. burgdorferi) is a serious medical, biological and medico-social problem due to the tendency to develop chronic diseases of apparatus that leads to adverse effects prolonged disability and disability of people of all ages and genders. 
Огляди літератури, оригінальні дослідження, погляд на проблему, випадок з практики, короткі повідомлення

The aim - establish clinical features of RA associated with B.burgdorferi.

Material and Methods. 63 patients in the age between 19 and 73 participated in our study. They were examined in the Rheumatology Department of Ternopil University Hospital. There were 19 (30.15 \%) men and 44 (69.85\%) women. Patients were divided into 2 groups: 34 (group 1) - patients with RA associated with B. burgdorferi, 29 (group 2) - isolated RA. The diagnosis of RA has been verified according to the classification criteria (ACR/EULAR 2010). A visual analogue pain scale (VAS) was used to analyze the pain intensity, a DAS 28 activity scale was used to characterize RA activity.

Results. The study found that the presence of B. burgdorferi in patients with RA was associated with faster development of the disease and a high degree of activity of the inflammatory process. Among those examined with laboratory-confirmed B. burgdorferi, there was a great number of patients positive in anti-CCP and RF. Among the group examined for RA with $B$. burgdorferi showed a high percentage of patients with Baker's cysts and structural changes on the radiograph. The rates of pain syndrome by VAS were significantly higher in patients with RA associated with B. burgdorferi $(p<0.05)$.

Conclusions. It was demonstrated that the presence of $B$. burgdorferi in the group of patients promotes the progression of arthritis, causes a more severe clinical picture of the disease and is a predictor of the development of a more pronounced degree of joint destruction.

KEY WORDS: rheumatoid arthritis; Borrelia burgdorferi; diagnostics; Baker's cysts; Lyme arthritis.

Отримано 22.10.2019 